\title{
State Capacity in Implementing the Covid- 19 Vaccination Program in Indonesia
}

\author{
Sitti Aminah ${ }^{1 *}$, Slamet Rahmat Topo Susilo ${ }^{2}$ \\ ${ }^{1}$ Research and Development Board Ministry of Home Affairs \\ Kramat Raya Street No 132, Center Jakarta \\ ${ }^{2}$ Ministry of Villages, Development of Disadvantaged Areas and Transmigration \\ Kalibata TMP No 17 South Jakarta \\ Corresponding Email: sittiaminah.kemendagri@gmail.com
}

\begin{abstract}
The threat of the Covid-19 pandemic has pushed every country to protect its citizens; one form of protection is implementing the Covid-19 vaccination program. The study aims to explore the state's capacity in implementing the vaccination program. The study uses the literature review method, sourced from scientific journals, books, and other information sources. The study results show that the state capacity in implementing the vaccination program is classified as good in the dimensions of operational capability, budgetary capacity, institutional capacity, and analytical capacity. Although the size of operational capacity, the obstacle of vaccine procurement causes vaccination targets not to be achieved. The cold chain is insufficient in some areas, including the slow distribution of vaccines due to geographic constraints on the dimension of institutional capacity.
\end{abstract}

Keywords: State Capacity, Covid-19 Vaccination

\section{INTRODUCTION}

State capacity is tested when it was facing a pandemic. In a pandemic situation, the enemy faced is a virus that is invisible and spreads massively to infect humans, even causing death. Any country, including Indonesia, does not efficiently solve the Covid-19 pandemic. The threat of the pandemic has pushed every country to rise become a strong country. According to Dutton, even though the American military is known to be strong, they have been trying hard to fight the Spanish flu pandemic that existed 100 years ago until today (Dutton et al., 2021).

Indonesia also has to fight against Covid-19. From March to December 2020, the number of infection and death cases continues to increase. Of the 234 countries affected by Covid, Indonesia has ranked 20th with $1,487,541$ points of disease and 40,168 deaths. Due to Covid-19 per 1 million population, deaths are 147, while the global average of fatalities is 351 (Worldometer.info, March 26, 2020).

In the perspective of Fukuyama (2020), a "strong state" will play an essential and significant role in protecting and saving its citizens. State capacity became one aspect that determines a country's success or failure to solve the Covid-19 pandemic, besides the public trust and the leading factors. A country that has competent governments will formulate the right policies and steps to solve the pandemic.

In this paper, the authors review the literature about state capacity and then discuss the state capacity in implementing the vaccination program in Indonesia. The study uses the literature review method that is sourced from scientific journals and books, including government documents and online media.

\section{STATE CAPACITY}

The state capacity introduced by the historical sociologist Charles Tilly; the state capacity originally referred to the state's power to increase revenue. It then expanded to the state competency in the development process: enforce and support the market through regulation (Besley and Persson, 2010). State capacity is a core concept in political science research. It is widely recognized that state institutions exert considerable influence on economic development, civil conflict, democratic consolidation, and international security (Hanson \& Sigman, 2019).

State capacity explains various economic development perspectives, civil conflict, law and 
human rights, and the consolidation of democracy (Besley and Persson, 2010; Hanson \& Sigman, 2013). The state's capacity to raise taxes, regulate economic activity, and protect its citizens from crime varies in different countries (Besley and Persson, 2010). State capacity is defined as the state apparatus's willingness and capability to organize government policies that reflect the degree of government ability to control its agents, not to be free or arbitrarily enjoying patronage, corruption, and oppression (Englehart, A. N, 2009). Hendrix analyzes the state capacity to solving civil conflict (Hendrix, 2010). While Khemani explores the state capacity from the perspective of the economic theory "principal-agent relationships," the crux of state capacity is bureaucracies' culture - the incentives, beliefs, expectations, or norms shared among states personnel about how others are behaving (Khemani, 2019).

It can be concluded that the concept of state capacity is the capability of the country to organize various policies, including economic (income), law and human rights, civil conflict, international security, and organizational culture. The core of state capacity is the country's capability or the government to organize policies to respond to problematic situations for the expected goals.

Some experts have mentioned some dimensions for measuring the state capacity. Grindle notes four sizes to measure economic and social development in Africa and Latin America: Institutional Capacity, Technical Capacity, Administrative Capacity, and Political Capacity (Grindle, 1996). Hands-on and Sigman suggest three state capacity dimensions: Extractive Capacity, Coercive Capacity, and Administrative Capacity (Hanson \& Sigman, 2019). In the social conflict perspective, state capacity dimensions include Military Capacity, Bureaucratic Capacity, and Expert Assessment (Hendrix, 2010). From the local government's perspective, the state capacity is viewed from Political Capacity, Institutional Capacity, Administrative Capacity, and Technical Capacity (Reddy et al., 2015). Finally, the state capacity in the perspective of solving a pandemic is viewed from Operational Capacity, Fiscal Capacity, Analytical Capacity, and Political Capacity (Woo, 2020).

This paper highlights state capacity, which focuses on the government's capability to implement vaccination programs in the dimensions of Operational Capacity, Budget Capacity, Institutional Capacity, and Analytical Capacity.

\section{COVID-19 VACCINATION PROGRAM}

The vaccination program is one of the longterm solutions to solving the Covid-19 pandemic because the vaccination program has clinical and socio-economic benefits, significantly increasing society's immunity. (Deroo et al., 2020). Indonesia became the first country in Southeast Asia to implement the Covid-19 vaccination program. The legal basis for implementing the vaccination program in Indonesia is President Regulation Number 99 the Year 2020 about the procurement of vaccines and its implementation in 2021 and the 1st quarter of 2022.

The government target for national vaccination is $60-70$ percent or about 181,5 million of the 269,6 million population. 181,5 million obtained from the population over 18 years is 188,7 million minus 7,2 million population of "exclusion." The category of "exclusion" is pregnant women, the people exposed to Covid-19, and uncontrolled comorbidities (Table 1)

Table 1 Population Targeted of the Vaccination Program

\begin{tabular}{|l|l|}
\hline Total population & 269,6 million \\
\hline Population $>18$ years & 188,7 million \\
\hline $\begin{array}{l}\text { Exclusion (pregnant women, } \\
\text { exposed to covid-19, comorbid) }\end{array}$ & 7,2 million \\
\hline $\begin{array}{l}\text { Population }>18 \text { years which can be } \\
\text { vaccinated }\end{array}$ & 181,5 million \\
\hline
\end{tabular}

Sources: Ministry of Health, Republic of Indonesia, 2021.

The government estimates that the need for a vaccine for the 181,5 million population is 426,8 million doses of vaccine; this number takes into a 60 percent efficacy rate and assumes 100 percent herd immunity coverage. Total vaccine 426.800 .000 has been considered a wastage rate of 15 percent or damage level, depreciation, or loss by 15 percent (Ministry of Health, Republic of Indonesia, 2021).

The implementation of the Covid-19 vaccination program will be held for 15 months and will be carried out in two stages. The first stage is January 2021 to April 2021 and has vaccinated 1,4 million medical personnel, 17,4 million public service workers, and 21,5 million older adults. The second stage of vaccination is scheduled for April 2021 to March 2022; the vaccination target is 63,9 million people at high risk of infection and 
other communities with a cultural approach (Ministry of Health, Republic of Indonesia, 2021).

\section{OPERATIONAL TECHNICAL CAPACITY}

The operational capacity dimensions include the government's ability to procure Covid-19 vaccines, vaccinators, and infrastructure.

The procurement of Covid-19 vaccines. For the needs of 426,8 million vaccines, the procurement of vaccines by the government through the purchase of vaccines from the overseas; collaboration with the Coalition for Epidemic Preparedness Innovation (CEPI) and Global Alliances for Vaccine and Immunization (GAVI), and develop the Red-White vaccine independently in the country (Ministry of Health, Republic of Indonesia, 2021). The collaboration has started in December 2020 and 2021 (quarters 1 to 4). It will be completed in the first quarter of 2022, with the following types and quantities of vaccines: Sinovak (125.504.000 doses), Novavax (130.000.000 doses), Covax/Gavi (78.000.000 doses), AstraZeneca (65.296.000 doses), and Pfizer (28.000,000 doses) (Ministry of Health, Republic of Indonesia, 2021).

The main challenge of vaccine procurement is the limited number of vaccines. In January and February, the available vaccine is only three million doses, so the vaccine is only given to 100.000 people.
It means that the government cannot achieve the target, that is 900.000 to 1 million people per day. Because if 1 million vaccines per day, the vaccine will run out within three days. This condition can cause local government protests (Liputan 6.Com, March 15, 2021). One of the affecting factors is the increasing need for the Covid-19 vaccine globally, which causes Indonesia to compete with developed countries; on the other hand, there are differences in vaccine markets between developed and developing countries. Developed countries with $15 \%$ of the world population have a global percentage of vaccine sales by $82 \%$. In comparison, developing countries with $85 \%$ of the world population have a global share of vaccine sales by $18 \%$ (Laksono et al., 2018).

Availability of vaccinators. The vaccination program' 1.770 vaccine implementers (vaccinators) vaccinators are general practitioners, specialist doctors, nurses, and competent midwives because they have been previously trained. The number of vaccinators in each region is presented in Figure 2.

Infrastructure capacity. Supporting health service facilities for vaccination, the government provides 10,166 health service centers in each district, government hospitals (Ministry / Army / Police / Local Government), private hospitals, and 49 port health offices throughout Indonesia. Vaccination service requirements have several criteria: 1 . Have a competent vaccinator, 2. According to the type of Covid-19 vaccine, have a cold chain and have an operational permit 3-storage capacity in each area.

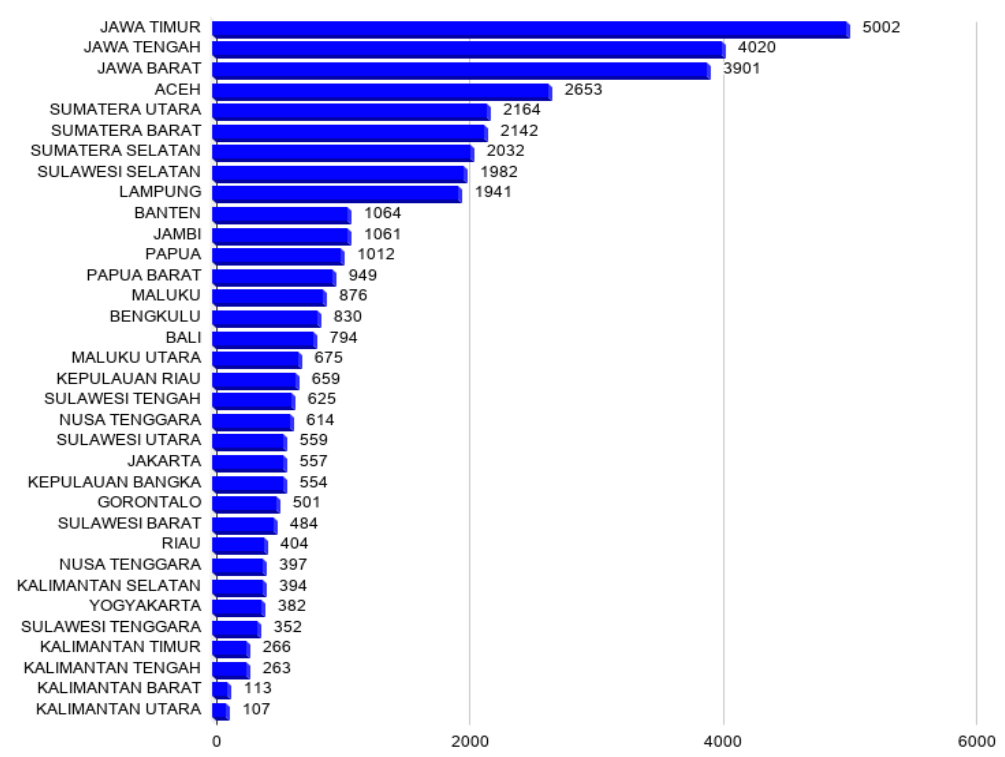

Figure 1. The vaccinator's number across 34 provinces in Indonesia (Source: Ministry of Health of the Republic of Indonesia). 
Infrastructure capacity. Supporting health service facilities for vaccination, the government provides 10,166 health service centers in each district, government hospitals (Ministry / Army / Police / Local Government), private hospitals, and 49 port health offices throughout Indonesia. Vaccination service requirements have several criteria: 1 . Have a competent vaccinator, 2. According to the type of Covid-19 vaccine, have a cold chain and have an operational permit 3-storage capacity in each area.

More than 90 percent of the cold chain that maintains vaccine quality during area distribution is available at the public health center (Ministry of Health, 2021). However, it is not sufficient in some areas (South Sumatra and North Sumatra). Cold chain insufficiency occurs because it is still used for noncovid-19 vaccines, hampered by service during the pandemic (Kompas.com, January 29th, 2021). The availability of a cold chain is critical; for example, the Covid-19 vaccine made by Sinovac must be stored in a temperature range of about 8 degrees Celsius, so its quality is maintained.

\section{HEALTH BUDGET CAPACITY}

According to the Indonesia Health Law, the government consistently maintains the health budget of $5.5 \%$ of state spending, the health budget has increased since the last five years, the health budget for 2016 is IDR 92.3 trillion, 2017 is IDR 104.9 trillion, 2018 is IDR 111.0 trillion, 2019 is IDR 123 trillion, and 2020 is IDR 212.5 trillion. In 2021, the health budget allocation fell to IDR 176.3 trillion (Ministry of Finance, 2021). According to economic expert Faisal Basri, the decrease in health budget shows the lack of government's commitment to overcoming the Covid-19 pandemic; on the other hand, the infrastructure budget has increased from IDR 281.1 trillion in 2019 to IDR 414 trillion or twice of health budget (Kontan. co. id, December 18th, 2020). In 2021, the health budget focuses on testing and tracing IDR 9.91 trillion; maintenance costs IDR 61.94 trillion; vaccination programs IDR 58.18 trillion; health tax incentives IDR 18.61 trillion activities IDR 27.67 trillion (Ministry of finance, 2021). The vaccination budget also comes from the APBD to finance operational activities, vaccine distribution, development and dissemination of communication materials, information and education on vaccination programs, advocacy meetings, coordination and socialization, and post-immunization follow-up surveillance events.

\section{INSTITUTIONAL CAPACITY}

Institutional capacity is viewed by distribution and public communication capacity.

Distribution Capacity. Vaccine distribution from vaccine developers under the Ministry of Health coordination continues to the packaging at Bio Farma. Bio Farma is recognized as an Indonesian vaccine development institute according to WHO standards. From Biofarma, vaccines were distributed to 34 Provinces and 514 districts and cities. Institutions that play a role in distribution include the Ministry of Health, Local Government (Provincial and District / City Health Offices), regional hospitals, and health clinics. Indonesia's army and Police have a role in preserving during the distribution process (Figure 2). Large and small islands of Indonesia's geography are an obstacle for distributing the vaccine, especially in remote areas with limited accessibility.

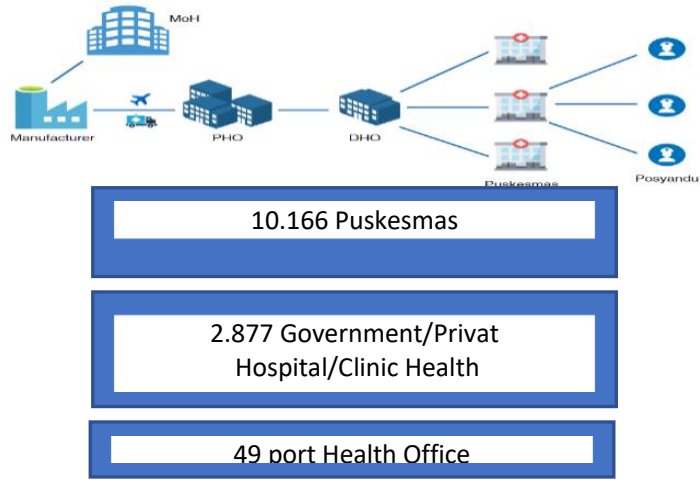

Figure 2. Distribution of Vaccine System 
Public Communication. The government has prepared an official information channel to inform about the Covid-19 vaccination, http://s.id/infovaksin. Some of the other official government information channels include 1. Whatsapp: bit.ly/vaksincovid. 2 Blast message: PEDULICOVID. 3 Email: vaccines@pedulilindungi.id 4. Website: peduli.lindungi.id. 5. Call/UMB*119\# 6. Vaccination hotline for COVID-19: 119 ext 09. The existence of these various information channels is essential to deliver the correct information about vaccination.

The government's ability to eliminate "infodemic," namely redundant information, shares quickly to the public in the news, pictures, and videos. For example, to filter hoax information, on the link http://s.id/infovaksin, there is a "check and prove hoax" feature. Massive information dissemination of Covid-19 vaccination will eliminate negative messages about vaccines and, in the end, will increase public trust in the government's efforts to reduce the number of infections and deaths due to the Covid-19 pandemic through vaccination implementation program in Indonesia.

\section{ANALYTICAL CAPACITY}

Analytic capacity. The use of technology applications for the Covid-19 vaccination program ensures the Covid-19 vaccine is safe and on target by using logistic monitoring applications, Bio tracking, and SMILE (Electronic Logistics Immunization Monitoring System). Bio tracking to determine vaccine distribution information is: real-time movement position, temperature, track door sensor, checkpoint, and bio detect travel flow. During the vaccine's area distribution process, a freeze alert is provided to determine the vaccine's quality. The SMILE application will inform Covid-19 vaccine distribution data at each stage: quantity, batch number, and expiration date.

SMILE application is connected to a temperature monitoring and recording device for the Covid-19 vaccine so that officers can monitor temperatures through the application. The government also uses the Covid-19 Vaccination One Data Information System to facilitate data collection on the target participants for vaccination (vaccine recipients). How the system works are: first, the target receives a notification through message Blast. Second, confirmation or re-registration of vaccine recipients, including choosing place and schedule of vaccination services, and third, electronic tickets for verified targets. The use of the Petcare application helps officers ensure a high index of vaccine usage (IP), so health centers and health care facilities can contact targets before the day of service to ensure the arrival of vaccination participants.

\section{CONCLUSION}

The country's capacity for implementing the Covid-19 vaccination program is good in all dimensions. The government has procured the covid19 vaccine in the operational capacity dimension, prepared competent vaccinators, and adequate infrastructure. Even though there are problems with the insufficient covid-19 vaccine due to competition between states globally, the target of 900-1 million per day is not achieved. Including the readiness of inadequate cold chain facilities in some areas. In the budget capacity dimension, the government has allocated a budget for vaccination, although in general, the health budget allocation has decreased compared to 2020. Institutional capacity, the government has distributed all regions, starting from vaccine developers, packaging for Covid-19 vaccines at Bio Farma, and distribution throughout the area with the security of Indonesia's army and Police. Public communication capacity can be seen from the availability of official channels and various channels to eliminate infodemics. In the dimension of analytic ability, the use of information and communication technology with the help of logistic monitoring applications, Bio tracking, and SMILE, and the Covid19 Vaccination One Data Information System has facilitated the implementation of the Covid-19 program in the regions.

\section{REFERENCES}

[1] Besley Timothy and Persson, T. (2010). State Capacity, Conflict, and Development. Econometrica, 78(1), 1-34. https://doi.org/10.3982/ecta8073

[2] Deroo, S., Sarah, Pudalov, J., N., \& Fu, L. Y. (2020). Planning for a COVID-19 vaccination program. JAMA - Journal of the American Medical Association, 323(24), 2458-2459. https://doi.org/10.1001/jama.2020.8711

[3] Dutton, L. K., Rhee, P. C., Shin, A. Y., Ehrlichman, R. J., \& Shemin, R. J. (2021). 
Correction to: Combating an invisible enemy: the American military response to global pandemics (Military Medical Research, (2021), 8, 1, (8), 10.1186/s40779-021-00299-3). Military Medical Research, 8(1), 1-10. https://doi.org/10.1186/s40779-021-00304-9

[4] Englehart, A., N. (2009). State capacity, state failure, and human rights. Journal of Peace Research, $46(2)$ $163-180$. https://doi.org/10.1177/0022343308100713

[5] Grindle, Merilee Serrill Grindle. Challenging the State: Crisis and Innovation in Latin America and Africa Cambridge University Press

[6] Hanson, J., \& Sigman, R. (2019). Leviathan's Latent Dimensions: Measuring State Capacity for Comparative Political Research. Manuscript, Maxwell School of Citizenship and Public Affairs, Syracuse University, 1-41. http://faculty.maxwell.syr.edu/johanson/papers/ha nson_sigman13.pdf

[7] Hendrix, C. S. (2010). Measuring state capacity: Theoretical and empirical implications for the study of civil conflict. Journal of Peace Research, 47(3), 273-285. https://doi.org/10.1177/0022343310361838

[8] Khemani, S. (2019). What Is State Capacity? In What Is State Capacity? (No. 8734; Issue February). https://doi.org/10.1596/1813-94508734

[9] Laksono, H., Maryadi, P., Dewi, E. D., Aryadi, T., Santikajaya, A., Fitri, W., \& Putro, robertus A. (2018). "Kesehatan untuk Semua: Strategi Diplomasi Kesehatan Global Indonesia ." In Jakarta. Badan Pengkajian dan Pengembangan Kebijakan Kementerian Luar Negeri RI.

[10] Reddy, P., Nemec, J., \& De Vries, M. S. (2015). The state of local government. Public Policy and Administration, 14(3), 160-176. https://doi.org/10.5755/j01.ppaa.14.3.13430

[11]Woo, J. J. (2020). Policy capacity and Singapore's response to the COVID-19 pandemic. Policy and Society, 39(3), 345-362. https://doi.org/10.1080/14494035.2020.1783789

[12]Fukuyama, Francis. 2020. "The Pandemic and Political Order: It Takes a State." Foreign Affairs, July/August $2020 . \quad$ [daring] https://www.foreignaffairs.com/articles/ world/2020-06-09/pandemic-and-political-order. [accessed on August 19 ${ }^{\text {th }}, 2020$ ].

[13] CNN, 20121. https://www.cnnindonesia.com/nasional/2021030 3134243-20-613186/menkes-target-vaksinasi-1juta-orang-sehari-bisa-dimulai-juni.

[14] CNN 2021 https://www.cnbcindonesia.com/tech/2021020117 1626-37-220242/baru-42800-per-hari-vaksinasicovid-ri-berjalan-lambat

[15] Merdeka.Com (4 Februari, 2021). Ombudsman Ingatkan Potensi Masalah Limbah Vaksin Covid19. https://www.merdeka.com/uang/ombudsmaningatkan-potensi-masalah-limbah-vaksin-covid19.html

[16]Liputan 6.Com, 15 Maret, 2021. Masalah Ketersediaan, Alasan Indonesia Belum Bisa Suntik 1 Juta Vaksin COVID-19 per Hari. https://www.liputan6.com/health/read/4506274/m asalah-ketersediaan-alasan-indonesia-belum-bisasuntik-1-juta-vaksin-covid-19-per-hari

[17] Kompas.Com, 29 Januari 2021. Satgas ungkap kendala vaksinasi covid-19, penerima tak hadir hingga cold chain yang tidak cukup.

[18] https://nasional.kompas.com/read/2021/01/29/085 53941/satgas-ungkap-kendala-vaksinasi-covid19-penerima-tak-hadir-hingga-cold?page=all

[19] Kontan.co.id. 18 Desember 2020. Faisal Basri: Anggaran Kesehatan 2021 turun Dari 2020, bukti tidak ada komitmen pemerintah.https://nasional.kontan.co.id/news/fais al-basri-anggaran-kesehatan-2021-turun-dari2020-bukti-tak-ada-komitmennegara\#: :text=Di\%20Indonesia\%2C\%20anggara n\%20kesehatan\%20tahun,sebesar\%20Rp\%20212 $\% 2 \mathrm{C} 5 \% 20$ triliun.

[20] Radzi, N., Sari, A. L., \& Irwandi. (2019). Islamic Education in Singapore: Case Study Madrasah Al-Juneid Al-Islamiyah. International Journal of Science and Society, 1(2), 14-26. https://doi.org/10.200609/ijsoc.v1i2.10

[21] Wildan, A. D. (2021). Handling the COVID-19 Pandemic through an Islamic Perspective. ENDLESS: International Journal of Future Studies, 4(2), 31-42. 